\title{
Supported Decision Making Model as a Tool and Form for Socialization of People with Psychosocial Disabilities: Legal and Social Education Challenges in Lithuania
}

Dovilè Juodkaitè

Association “Lithuanian Forum for the Disabled”, Žemaitès St. 21, LT-03118 Vilnius, Lithuania, dovile.juodkaite@gmail.com

The aim of this article is to introduce the new concept of supported decision making model. Supported decision making model (SDM) as a tool for proper implementation of the rights of persons with disabilities is foreseen in the newest international human rights treaty - Convention on the rights of people with disabilities (CRPD). As a new concept SDM raises number of challenges both of legal, social and educational aspects how to introduce and implement this model in practice in order to safeguard rights and ensure social integration and socialization of the most vulnerable persons with psychosocial disabilities in the society.

Specific objectives of the study carried out were: to review new legal requirements of art. 12 of CRPD for ensuring equality before the law for all persons with disabilities, to critically analyze Lithuanian legal guardianship system for its compliance / noncompliance to those international requirements; to review and analyze supported decision making models existing in other countries; based on the comparative analysis of the supported decision making models, to make recommendations for Lithuanian legislation, legal and social practice on possible supported decision making model.

Keywords: persons with disability, social integration, rights of disabled, equal recognition before the law, supported decision making. 


\section{Introduction}

On the international level Universal declaration on human rights (1948) was the first to formulate rights and moral norms, establishing principal of protecting an individual as the highest value, which was later on included in all main international (CCPR, 1966; CESC, 1966; CEDAW, 1979; CAT, 1984; CRC, 1989), regional (ECHR, 1950) and national legal documents. Human rights and freedoms are considered as the principal values of modern democratic states, thus their effective realization, legal safeguarding and protection is one of the main goals of the state and society. It is universally acknowledged that human rights shall be secured to everyone without any discrimination. Nevertheless, historically people with disabilities based on an old fashioned medical approach have been regarded as "objects" of charity and medical interventions, that were most often based on special treatment schemes, care models, often far removed from ordinary social life, and resulting in social isolation or even deprivation of liberty. It is only in recent years disability became a new area of action in the protection of human rights. The most prominent achievement recently on the international level was adoption of UN Convention on the rights of persons with disabilities and its Optional Protocol (CRPD). For the first time on an international level all the rights of persons with disabilities were enshrined and formulated, bringing about a paradigm shift in attitudes of persons with disabilities as "subjects" of human rights. The new social model of disability highlights the fact that disability is a social relationship and that people with disabilities undergo the limitations and prejudices created by society (WHO Resource book, 2005). This approach emphasizes that disability depends on the interaction between environmental, social and personal factors. The more society embraces people's characteristics and develops their abilities, the more it is able to remove barriers, obstacles and prejudices.

\section{New legal capacity standards and introduction of supported decision making mechanisms}

One of the most substantive areas that demonstrates major 'paradigm shift' of CRPD is provision of equality before the law to all the persons with disabilities. The right to recognition everywhere as persons before the law puts an end to various practices of the removal of rights of persons depending on their health, disability status. Legal capacity is addressed in Article 12 of the Convention and has been the subject of extensive debate both during the process of adoption of the text of the Convention, as well as of its proper interpretation and implementation.

With its purpose to "promote, protect and ensure the full and equal enjoyment of all human rights and fundamental freedoms by all persons with disabilities, and to promote respect for their inherent dignity", CRPD seeks to shift the way all people with disabili- 
ties are treated from objects of pity, management, treatment and charity - to subjects of human rights in all areas of life on an equal basis with others. Art. 12 of CRPD indicates one of the most important right to legal capacity ${ }^{1}$. Article 12 (1) reaffirms that all persons, including all persons with disabilities, have the right to recognition before the law, and thus should be recognized as holders of rights and possessors of duties under the law. The notion "equal recognition before the law" sets the principle that disabled persons, like other citizens, have the right to have their status and capacity to be recognized in the legal order. Equality before the law is a basic general principle of human rights protection and is indispensable for the exercise of other human rights.

Article 12 (2) recognizes the right to the equal enjoyment of legal capacity. Herein "legal capacity" includes the capacity of the individual to be subject of rights and obligations as well as the capacity to $\mathrm{act}^{2}$. Legal capacity and mental capacity are distinct concepts. Legal capacity is the ability to hold rights and duties (legal standing) and to exercise those rights and duties (legal agency). It is the key to accessing meaningful participation in society. Mental capacity refers to the decision-making skills of a person, which naturally vary from one person to another and may be different for a given person depending on many factors, including environmental and social factors, socialization experiences, etc.

The right to equal recognition before the law implies that legal capacity is a universal attribute inherent in all persons by virtue of their humanity and must be upheld for persons with disabilities on an equal basis with others. In the paradigm shift of Art. 12 personal autonomy and self-determination are central elements. Self determination focuses on developing skills and supports that preserve and enhance, rather than limit, the person's ability to exercise choice in all facets of his or her daily life. And the ability to make one's own decisions based on personal values and in the context of meaningful choices is a defining feature of what it means to be a person, having social status and participating amongst other members of society as a full citizen. This paradigm shift opposes the previous assumption that because of persons' impairments and the need for support and care, his/her opportunities for meaningful participation and socialization should be limited, and others should make decisions on their behalf followed by legal restrictions of capacity, such as guardianship. The definition of disability in the context of social barriers is crucial in this paradigm shift. Social model of disability is applicable in relation to legal capacity in the way, that it is not the individual's „deficiency” in de-

1 In the sense of capacity to act, which is both the right to make decisions, and a legal status of persons with disabilities equal with other adults.

2 As the Office of the High Commissioner for Human Rights pointed out, the two terms "recognition as a person before the law" and "legal capacity" used in Art. 12 are distinct. The concept of legal personality (derived from art 12(1) CRPD) recognises the individual as a person before the law and is therefore a prerequisite for the enjoyment of any other right, while the "capacity to act" is intended as the capacity and power to engage in a particular undertaking or transaction, to maintain a particular status or relationship with another individual, and more in general to create, modify or extinguish legal relationships. 
cision-making that results in incapacity. It is the societal response to those persons who seek assistance in decision-making that legally incapacitates the person via guardianship systems (Gabor Gambos presentation, 2010). Thus guardianships of any type, whether limited or complete, defeat the self determination concept, and is incompatible with the requirements of Art. 12.

Legal capacity as it is used in the CRPD is a social and legal status accorded independent of a person's particular capabilities ${ }^{3}$. Social model approach to defining legal capacity focuses not on the individual's attributes or relative limitations, but rather on the social, economic and legal barriers a person faces in formulating and executing individual decisions, and the supports and accommodations they may require given their particular decision-making abilities (Michael Bach \& Lara Kerzner, 2011).

Article 12 also states that, when needed, people should be given support in exercising their legal capacity. Article 12 (3) requires the adoption of supported decision making (SDM) mechanisms for realization of legal capacity. SDM starts from the full and equal legal capacity of all citizens, even those with severe and profound levels of disability, together with the right to receive appropriate support and necessary safeguards, including in decision-making. More concretely it requires putting in place appropriate measures to provide access by persons with disabilities to the support they may require in exercising their legal capacity and thus preserving dignity and enabling individual autonomy and social inclusion. In this the account must be taken to the proportionality of the assistance or support measures to the degree of disability, and respect as much as possible, the rights to self-determination (EDF, DOC-B-08-11-05). Assisting the person to make a decision personally instead of having someone else making a decision for the person (known as substituted decision making) is crucial. Even if the particular individual with disability may need $100 \%$ supports (provision of which may seem similar to substituted decision making), the person's legal capacity on an equal basis with others must be respected. There are key elements indicated of a SDM model:

a) Allowing a person to continue to be entitled to exercise his/her legal capacity independently, on his / her own, including the right to dispose of their property and to manage related matters, the right to work, marriage, the right to vote, etc.

b) Comprehensive approach taken by the States towards SDM. Not only replacing the term "guardianship" or "curatorship" found in existing statutes with a more politically correct term, such as "support person" or "legal mentor", but fully implementing SDM model that encompasses elements of accessibility and reasonable accommodation.

3 The Legal Opinion of IDA illustrates that description of what legal capacity means for people who do not have disabilities is crucially different. A non-disabled citizen who owns real estate, or a car is entitled to sell the house, to hire the car, etc. All these and similar dispositions as an owner are a part of his or her legal capacity. Defined in this way, legal capacity does not reflect an individual's ability to make decisions. Rather, it reflects an individual's right to make decisions and have those decisions respected, and signals a social model approach to defining and understanding disability. 
c) Finally, SDM mechanism should be flexible and adaptable to a diverse range of circumstances, in order to be tailored to different personal and social situations ${ }^{4}$.

While introducing the SDM mechanism CRPD gives the presumption always in favour of the person with a disability who will be affected by the decision. (UN, 2007). In addition it requires introduction of full range of supports and services that would assist people with disabilities to exercise his/her legal capacity to the greatest extent possible, according to the wishes of the individual. In other words SDM enables a person to make his/her own decisions with the help of others. Essentially SDM is understood as a process of decision making that is directed by an individual but engages people who respect and are totally committed to that individual's well being and best interest, whereby individuals can realize their right to make their own decisions, and not about the outcome of a decision, not the individual's "competency" to make a decision. SDM pursues the right for people to have support in making decisions.

Article 12 (4) of CRPD sets forth minimum safeguards to control the effective application of any SDM mechanism. These safeguards should include an obligation on the support provider to assist the disabled person to make decisions, and not substitute his/ her will and preferences. Safeguards are needed in order to prevent abuse of supported decision-making arrangements. They should include legal measures to ensure that such arrangements:

a) respect rights of persons with disabilities and their will and preferences;

b) are free from conflict of interest and undue influence;

c) are proportionate to the person's need for assistance, and are the least restrictive necessary, and tailored to the circumstances and needs of the specific individual to whom they relate;

d) are limited and last only for the period they are required; and

e) are subject to regular review by an independent and impartial authority ${ }^{5}$.

4 Thus distinguishing between the „type of support needed for transactions which have vital consequences for the person's life or patrimony (e.g. marriage, adoption, donation, buying or selling property), and transactions involved with daily needs (e.g. traveling, applying for membership of a society or club etc) maybe needed.

5 Even if Art. 12 does not directly prohibit substituted decision making and guardianship systems, if applying the above mentioned principles (effectiveness, respecting will and preferences, necessity and proportionality) to the guardianship, it obviously show that this system fails to comply with those:

- If talking about the purpose of guardianship, which is protection of the person, then partially it corresponds to effectiveness test. But it is though clearly ineffective to protect and promote rights of persons. Rights abuses are prevalent in respect of persons under the guardianship;

- Preference and will of the person is not respected in applying legal incapacity and guardianship measures;

- Necessary for applying support measures to persons in need. Certainly there are persons who find difficult to make their own decisions without support. But, arguably there are less intrusive alternatives (without restricting persons rights and freedoms);

- Proportionality. In the case of plenary guardianship, civil death is hardly proportionate to the protection provided, not even measuring and considering human rights abuses that are prevalent with regards to persons under guardianship. 
Thus generalizing all the above mentioned it can be said, that SDM systems recognize the natural inter-dependence of human beings and adhere to the following principles:

- the adult retains full legal capacity whilst receiving services from a support person / network;

- a support person / network should not be appointed without the adult's consent;

- there must be a relation of trust between the adult and the supporting person / network;

- a court should therefore not create such relationship, only recognize its existence;

- the support person / network should not act on behalf of the adult. This role is limited to merely providing the adult with support and assistance in making and communicating decisions.

- there must be safeguards in place to protect the adult against abuse and exploitation.

Based on the jurisprudence of the CRPD Committee and concluding observations with regards to the reviewed countries there is an authoritative interpretation of the provisions of art. 12 provided in General Comment No.1. Concrete legal characteristics and mandates are required with regards to implementation of Art. 12 to follow during the drafting process of the new legal capacity provisions on national level:

i. review the laws allowing for guardianship and trusteeship;

ii. repeal the laws, policies and practices which permit guardianship and trusteeship for adults;

iii. take action to develop laws and policies to replace regimes of substitute decision-making by supported decision-making;

iv. provide all relevant public officials, civil servants, judges, social workers and other stakeholders with training in consultation and cooperation with persons with disabilities and their representative organisations, at the national, regional and local levels, on the human rights model of disability and recognition of the legal capacity of persons with disabilities and on mechanisms of supported decision-making.

The CRPD Committee goes further and points out that a system of supported decision-making includes the following:

i. recognition of all persons' legal capacity and right to exercise it;

ii. accommodations and access to support where necessary to exercise legal capacity;

iii. regulations to ensure that support respects the person's autonomy, will and preferences and establishment of feedback mechanisms to ensure that support is meeting the person's needs;

iv. arrangements for the promotion and establishment of supported decision-making (CRPD/C/CHN/CO/1). 


\section{Challenges of introducing SDM mechanisms in Lithuanian laws, policies and practices}

Historically, many persons with disabilities have been subjected to laws and practices that deprived them of their legal capacity in a discriminatory manner under substitute decision-making regimes such as guardianship, conservatorship and mental health laws that permit forced treatment. Institutes of incapacity or limited capacity of adult people are established in almost all the world's jurisdictions. Special protection measures (guardianship, curatorship) used for safeguarding rights and interests of persons declared as incapable or with the limited capacity may differ in their content and form in different countries. Recently institutes of incapacity and guardianship have been considered to become one of the main problems of human rights of persons with mental health problems. Although created as "protective" mechanisms for safeguarding human rights, they often become reason for gross human rights violations with the thousands of victims (Guardianship project, MDAC).

Lithuanian was among other countries that signed CRPD and its Optional Protocol on the first day it opened for signature, 30 March 2007. The Law on ratification of UN Convention and its Optional Protocol was passed by the Parliament (Seimas) on 27 May, 2010. After deposit of documents for ratification CRPD entered into force in Lithuania on 17 September, 2010 and currently Lithuania has all legal obligations under CRPD. After the ratification of CRPD, concerns are being raised on the compliance of national legislation (both existing and draft laws) to the provisions of CRPD, including provisions on the equality before the law 6 .

Both full guardianship and partial guardianship (curatorship) meant to safeguard the human rights of vulnerable people lacking capacity exist in Lithuania. Adults, who due to their mental illness and/or intellectual disability are no longer able to care for their personal interests or their property and affairs are declared legally incapable and shall be placed under guardianship by a court judgment. Guardianship is established with the aim of exercising, protecting and defending the rights and interests of a legally incapable person. Guardianship of a person subsumes guardianship of the person's property, but if necessary, an administrator may be designated to manage the person's property. Full incapacity means that individuals lose all the civil, economic, political and other rights usually enjoyed by other adults?.

Notwithstanding that guardianship system in some other countries are applied as a last resort, in Lithuania the tendency is opposite. The number of persons declared

${ }^{6}$ Disability NGO representatives meeting with the Head of Parliament (Seimas), Parliament members, representatives of Ministries, other stakeholders on the effective implementation of UN Convention on the rights of persons with disabilities, on 24 September, 2010.

7 For instance, this includes the right to work - individuals are not able to sign a work contract, thus they cannot be legally employed and are technically legally prohibited from working. 
as incapable in the last few years was growing - only during the first half year of 2009 number of persons with established incapacity increased by 2.3 thousand; according to the data provided by the Notary house, there are 6555 persons declared by the court decision as being incapable in Lithuania in 2010 (Bernardinai.lt, 2011). From 1 January 2011 a Registry of persons declared as incapable or partially capable was established in Lithuania. Registry is receiving and maintaining data on all persons declared as legally incapable or partially capable in Lithuania. Registry data is not public. In the year 2012 there were around 6000 persons declared as totally incapable and around 50 persons declared as partially capable by the courts. This number may seem not so big, but if to compare with the total number of persons with mental health problems or intellectual disability in Lithuania, it becomes quite substantial ${ }^{8}$.

Both national monitoring reports (Monitoring report „Human rights in mental health care in Baltic States". Vilnius, 2006; ITHACA, 2010) as well as international reports (CPT) indicate the gaps in the existing guardianship system of the Republic of Lithuania'. Current Lithuanian legislation does not comply with principal of proportional and tailored to the person's circumstances support measures, because it does not provide for any alternatives to the incapacity and guardianship, and thus does not allow persons with disabilities in accordance with their understanding and skills to realize their legal capacity. Such lack of alternatives and support measures contradict to the provision of CRPD art. $12(3)^{10}$. Lithuanian law does not provide for limited term support measures. Guardianship is established to a person who has been declared legally incapable by the court. Since the law does not provide any alternative support measures for adults with mental health problems, legal incapacity and guardianship is of indefinite period. There are no requirements provided in legal framework for periodical reviews on decisions of incapacity and guardianship itself. Person deprived of legal capacity himself can not address the court asking to repeal the previous court decision on declaration of his incapacity and establishing his capacity. The court must designate psychiatric expertise to reassess mental health status of the person concerned. Therefore, guardianship is significant human rights issue affecting incapable individuals today in Lithuania, because it

8 According to the calculations provided by the non-governmental organizations representing people with intellectual disabilities and mental health problems there are around 32 thousand people with intellectual disabilities and mental health problems within the total number of persons with disabilities in Lithuania. Thus 1/5 part of those persons are being declared as being incapable. Data provided by the Lithuanian welfare society for persons with intellectual disabilities "Viltis" [last accessed at 07.01.2011]. Available at: http://viltis.lt/lt/news/ detail.php?ID=6999; and Lithuanian Welfare Society for People with Mental Illnesses [last accessed 10.02.2011]. Available at: http://www.lspzgb.lt.

9 They also provide recommendations for changing both legislation and practices of depriving people with intellectual disabilities and mental health problems of their capacity.

${ }^{10}$ Providing that "states parties shall take appropriate measures to provide access by persons with disabilities to the support they may require in exercising their legal capacity". 
has a profound effect on the lives of those placed under its protective status (Lithuanian guardianship system in the context of European Union declared values, 2007).

\section{Suggestions for possible SDM measures in Lithuanian context.}

Analyzes of the existing forms and examples of supported decision making models from other countries showed that SDM can take many forms. Support could take the form of one trusted person or a network of people; it might be necessary occasionally or all the time. It may even be just a written declaration of the preferences of the person with disability. CRPD requires the support should be based on trust, be provided with respect and not against the will of the person with disabilities. Those assisting a person may communicate the individual's intentions to others or help him/her understand the choices at hand. They may help others to realize that a person with significant disabilities is also a person with a history, interests and aims in life, and is someone capable of exercising his / her legal capacity.

Recognizing the right to support may require putting into place new laws, policies, programs and administrative systems that make SDM available to people with intellectual and other disabilities.

As indicated above in Lithuania up to now there is existing plenary guardianship system, with no other alternatives for support in realizing legal capacity and exercising rights for autonomy and self-determination. Yet there is a new draft of the Civil Code provisions prepared related to declaring person's incapacity and placing under guardianship. This draft law was rendered to the Parliament (Seimas) of the Republic of Lithuania for approval in 2 April, 2014 (Draft laws on amendments of the Civil code and Civil procedure code, 2014). Draft law contains provisions on supported decision-making, advance directives, and the possibility of restriction or denial of legal capacity in specific areas of life. In the draft law there is indicated that the court is entitled to specify the list of fields regarding which the person concerned will partially or fully lose their legal capacity, and the list of deprivation of rights can be so broad that it in fact may mean full incapacitation. While denial of legal capacity regarding the specified fields shall be reviewed in 1 year time, there is no statutory review established in case of restriction of legal capacity. The draft legislation still allows for leaving out the person concerned from proceedings because of their health condition. Not once concerns were raised by the disability NGOs on the implementation of Art. 12, but the argumentation and lobbying for abolishing of guardianship legislation is far beyond ${ }^{11}$.

\footnotetext{
${ }^{11}$ Disability NGO representatives meeting with the Head of Parliament (Seimas), Parliament members, representatives of Ministries, other stakeholders on the effective implementation of UN Convention on the rights of persons with disabilities, on 24 September, 2010.
} 
Notwithstanding that the Law on social services (2006) provides for the objective of social services ${ }^{12}$ - to create conditions for a person (family) to develop or to enhance the abilities and possibilities to independently solve his social problems, maintain social relations with society as well as to assist in the overcoming of social exclusion. Social services are not understood as and targeted to enhancing abilities for decision making capacities. The Catalogue of Social Services (2006) describes various social services that are provided for disabled persons, as well as other risk groups and individuals. Upon assessment of the degree of self-sufficiency, social services are provided in order to ensure the biggest possible self-sufficiency of disabled and old people. Even if they are supporting the person in need, for instance in training his social and independent living skills, providing consultations and information ${ }^{13}$ they are not formally acknowledged as being used to support person in realisation of his legal capacity. Thus there is a great need for developing new forms of support for persons with disabilities that would empower them in decision making abilities for proper realisation of their legal capacity.

In Lithuania there are few existing services and practices, as well as legal measures that could be used and included while developing support system for realizing legal capacity based on the SDM principals. Example of service that maybe taken as the bases for developing support scheme for persons with psycho-social disabilities - Patient's person of trust program. This innovative service of Patient's person of trust is being introduced and developed in Vilnius city since 2006. Although not directly linked to realization of legal capacity, this service is effective in supporting and safeguarding human rights of patients hospitalized in psychiatric hospitals.

Patient's Person of Trust program is aimed at guaranteeing patients' representation and their human rights in the process of treatment. Patient's Person of Trust program is a tool to prevent and monitor human rights violations independently in mental health care institutions $^{14}$. In the broader scope the Patient's person of trust program seek for equal opportunities for persons with mental disorders to integrate to society and contribute to construing a chain of mental healthcare services in Lithuania according to the priorities adopted in National Mental Health Strategy of 2007 (Models of implementation

\footnotetext{
${ }^{12}$ Social services shall be the services aimed at providing assistance to a person (family) who, by reason of his age, disability, social problems, partially or completely lacks, has not acquired or has lost the abilities or possibilities to independently care for his private (family) life and to participate in society.

${ }^{13}$ Those are general social services as described in the Catalogue of social services.

${ }^{14}$ Essential features of person of trust position are independence from mental healthcare institution and the full support of the patient in his relation with the healthcare institution. Person of trust assists the patient to realize his rights by performing three essential functions of his position: (1) mediation and representation in case of complaints (2) information carrier and (3) identification of the shortcomings of the system.
} 
of Person of Trust Program, 2010). During the years of implementation ${ }^{15}$, the Patient's Person of Trust programme has proved to be successful, but have both organisational and financial difficulties ${ }^{16}$.

Another example that could be mentioned as useful for supporting persons with mental disabilities is an innovative case management method used in provision of psychosocial rehabilitation services in Vilnius Centre for Psychosocial Rehabilitation. This method is based exclusively on choices and agreements made between for people with mental health problems and employees (case managers) ${ }^{17}$.

There are also few NGOs active in representing the rights of persons with intellectual disabilities and mental health problems. Those are: Lithuanian welfare society for people with intellectual disability "Viltis", Lithuanian Welfare Society for People with Mental Illnesses, Lithuanian organization of people with mental disorders „Giedra“, Club "13 and Co". Each and every of those provide support to persons in various ways (information, consultation, personal assistance, peer advocacy, etc.), that might be considered and formalized as support schemes for persons that are in need for assistance in making their own decisions and thus realizing their legal capacity.

Besides there are specific legal measures enshrined in the Civil Code that could be advanced and applied as support measures for persons in need of support in realising their legal capacity. For instance, powers of attorney, living wills, representation under the law, representation under the assignment ${ }^{18}$ (Civil Code, 2000). Those measures could be legally formulated to cover one or another aspect / area of support needed by persons in realizing their legal capacity.

\footnotetext{
${ }^{15}$ Non-governmental organization Globali iniciatyva psichiatrijoje in 2005 started initiating the new independent patients' rights monitoring measures in Lithuania. The model arose from Person of trust program that was adapted from the Netherlands pattern. This program was implemented in co-operation with Dutch specialists in order to spread the good practice in advocacy field. In 2006 Vilnius municipality has issued Vilnius mental health strategy and since then Person of trust program in Vilnius city is coordinated by Globali iniciatyva psichiatrijoje and financed by the local municipality.

${ }^{16}$ Unfortunately, the services of patient's person of trust at the moment are not available. While functioning in the years 2005-2011 this program covered people with mental health problems and sometimes people with intellectual disabilities during their in-patient stay in one of the Vilnius Mental Health Centre or out-patient treatment in two Mental Health Centres of Vilnius city.

${ }^{17}$ Case management is aimed at developing and maintaining the contact with person with mental health problems for finding the best possible support measures in a particular case. Case manager together with client (and his family members) develop an individual rehabilitation plan based on the wishes and needs of the person/persons, and proceed with the support required [last accessed at 10.07.2011]. available at: http://www.protnamis.lt/files/ Rekomendacijos_darbdaviams.pdf.

${ }^{18}$ Civil Code regulate various forms and cases of representation, rights and obligations of both parties that come into the representation agreement, consequences of such representation, etc.
} 


\section{Conclusions}

National legislation that allows for declaring a person as legally incapable conflicts with the recognition of legal capacity of persons with disabilities enshrined in article 12 (2). In the Concluding observations the Committee (Concluding observations, CRPD) not once stressed its concerns that no measures have been undertaken to replace substitute decision-making by supported decision-making in the exercise of legal capacity and recommended to take actions to develop laws and policies to replace regimes of substitute decision-making by supported decision-making. Abolishing norms that violate the duty of States to respect the human right to legal capacity of persons with disabilities is not enough. It is equally important that measures that protect and fulfill this right are also adopted, in accordance with article 12 (3), (4), (5). This includes: legal recognition of the right of persons with disabilities to self-determination; of alternative and augmentative communication; of supported decision-making, as the process whereby a person with a disability is enabled to make and communicate decisions with respect to personal or legal matters; and the establishment of regulations clarifying the legal responsibilities of supporters and their liability (OHCHR, 2009).

Lithuanian law has no instrument that would facilitate the exercise of legal capacity, as indicated in $\mathrm{CRPD}^{19}$. Precluding or generally limiting the legal capacity is in violation of the requirements of Article 12.4 in as much as these measures are not proportional and tailored to the person's circumstances ${ }^{20}$, and do not respect the person's will and preferences. Guardianship is not only disproportionate and unnecessary intervention into the autonomy of the individual, but in practice fail to provide protection, and make the person with disability even more powerless. Since after individuals are declared as lacking legal capacity to act, they are not only robbed of their right to equal recognition before the law, they are also robbed of their ability to defend and enjoy other human rights ${ }^{21}$. Currently the law does not provide any alternative support measures for adults with intellectual disabilities and mental health problems with decision making. Legal incapacity and guardianship is established for indefinite period. Besides, there are no requirements provided in legal framework for periodical reviews on decisions of incapacity and guardianship itself.

\footnotetext{
${ }^{19}$ Providing that "states parties shall take appropriate measures to provide access by persons with disabilities to the support they may require in exercising their legal capacity".

${ }^{20}$ It does not provide for any alternatives to the incapacity and guardianship, and thus does not allow persons with disabilities in accordance with their understanding and skills to realize their legal capacity.

${ }^{21}$ For instance, The Constitution of the Republic of Lithuania states in art. 34 that "persons being declared by the court as legally incapable may not participate in the elections", also they may not be elected as the members of Parliament (art. 56). There are provisions in the Civil code, that marriage can be concluded by the persons declared as incapable. Also, such person can not be his children' representative under the law, can not inherit any property, can not present and / or may not be a dower under the law. Requirements provided for the guardian itself are laid down in the Civil code and include legal capacity of the person to be appointed as a guardian.
} 


\section{Recommendations for Lithuania to effectively implement Art. 12 of CRPD and introduce SDM model}

Further recommendations are provided for Lithuanian legal and practical situation on effective implementation of art. 12.

1. Legal reform to meet CRPD art. 12 requirements. Firstly changing legal provisions of Civil Code to recognize equal rights of all persons to have and exercise legal capacity without discrimination based on disability, as well as introduce SDM mechanism to assist persons with disabilities to exercise their legal capacity. This legal reform should entail: a. abolishing plenary guardianship or any substituted decision-making mechanism that overrides a person's own will, whether it is concerned with a single decision or a longterm arrangement; $b$. introducing types of support and assistance schemes; $c$. establishing safeguards to ensure a high quality of support and its compliance with standards ${ }^{22}$.

Secondly, a systematic revision ${ }^{23}$ of all other areas of Lithuanian law (both disability and non-disability specific legislation) that contain elements of legal capacity and replacement of guardianship with $\mathrm{SDM}^{24}$.

3. A systematic revision of all existing programmes, practices, social schemes that currently provide support for persons with disabilities in their everyday life and decision making processes, in order they could be used as examples for alternatives to guardianship system, following the main principles of SDM.

4. Proposing the development of a national framework for SDM. This should include analysis of existing good examples of services and practices, introduces both by state agencies or non-governmental organisations. Development a different types of support in order to meet the wide range of needs among people with disabilities and allow for personal choice among different options. Administrative systems for managing SDM at a state-level (registration of representation agreements, court proceedings, authorities) should be established.

5. Supporting model programmes that popularise SDM. Providing capacity building and the education for NGOs', supporters through the financial support secured by the government.

6. Ensuring awareness raising in the judiciary, the civil service and society at large about the fact that persons with disabilities are persons with abilities who have will and can make decisions when assisted.

\footnotetext{
${ }^{22}$ Such as: respect for the rights, will and preferences of the person, freedom from conflict of interest and undue influence, and being tailored to individual circumstances.

${ }^{23}$ This revision should ensure, that all laws and mechanisms by which a person's capacity to act can be deprived or restricted, or a person maybe disqualified from enjoying rights or performing legal acts or responsibilities based on disability must be abolished or replaced with laws that recognize the right to enjoy and exercise legal capacity.

${ }^{24}$ Such as: Constitutional provision limiting the rights to participate in elections for persons being declared as incapable; etc.
} 
7. Ensuring scheme for transition period from changing the legal status of guardianship to regaining full legal capacity by provision of SDM measures, ensuring redistribution of existing resources.

8. Active involvement and partnership with people with disabilities and the organizations representing their interests in implementation of all aspects of Art. 12 (including the development and provision of support measures). This is of crucial importance since policies and legislations, when designed with the participation of the stakeholders they serve, are far more likely to be relevant, effective and tailored to the need ${ }^{25}$.

\section{Resources}

\section{International and national legal acts}

1. International human rights treaties: Universal Declaration of Human Rights (1948), followed by International Covenant on Civil and Political Rights (1966) and the International Covenant on Economic, Social and Cultural Rights (1966); Convention on Elimination of All Forms of Racial discrimination (1965); Convention on Elimination of Discrimination against Women (1979); Convention against Torture and other cruel, inhuman or degrading Treatment (1984) and Convention on the Rights of the Child (1989)

2. The Convention on the Rights of Persons with Disabilities and its Optional Protocol. Available at: http://www.un.org/disabilities/default.asp?navid=12\&pid=150 (last accessed at 10.12.2010)/ (CRPD, 2006)

3. Committee on the Rights of Persons with Disabilities, General Comment No. 1 (2014). Article 12: Equal recognition before the law. CRPD/C/GC/1. Available at: http://daccess-dds-ny.un.org/doc/UNDOC/GEN/G14/031/20/PDF/G1403120. pdf?OpenElement

4. Law on ratification of UN Convention the Rights of Persons with Disabilities and its Optional Protocol // State news, 2010, No. 67-3350

5. The Civil code of the Republic of Lithuania was adopted and entered into force in 2000. // State News , 2000, No. 74-2262.

6. The Code of civil procedure of the Republic of Lithuania was adopted and entered into force in 2002. // State News, 2002, No. 36-1340

7. Law on social services // Sate News, 2006, No. 17-589.

8. Catalog of Social Services // State News, 2006, No. A1-93

\footnotetext{
25 This is needed to ensure that persons with disabilities and their representative organizations are closely consulted with and actively involved in the development and implementation of legislation and policies relating to implementation of the CRPD and decision-making processes concerning persons with disabilities.
} 
9. Draft laws on amendments to particular articles of the Civil code and Civil procedure code of 2 April, 2014. No. XIIP-1656 and No. XIIP-1657.

\section{Literature}

10. World network of users and survivors of psychiatry. Implementation manual for the UN Convention on the rights of persons with disabilities. February, 2008.

11. Monitoring the Convention of the rights of persons with disabilities. Guidance for Human rights Monitors. Proffesional trainign series No. 17. NY and Geneva, 2010.

12. Report of the United Nations High Commissioner for Human Rights and reports of the Office of the High Commissioner and the Secretary-General. Thematic Study by the Office of the United Nations High Commissioner for Human Rights on enhancing awareness and understanding of the Convention on the Rights of Persons with Disabilities. A/HRC/10/48. 26 January 2009.

13. Study on challenges and good practices in the implementation of the UN Convention on the Rights of Persons with Disabilities VC/2008/1214. Final Report. European Foundation Center. Brussels, 2010.

14. Michael Bach \& Lana Kerzner. A new paradigm for protecting autonomy and the rights to legal capacity, 2011.

15. International Disability Alliance. Guidance document. May, 2010.

16. Equal recognition before the law and equal capacity to act: understanding and implementing Article 12of the UN Convention on the rights of persons with disabilities. EDF, DOC-B-08-11-05.

17. Decision making and Intellectual Disability: Supporting People to make their own decisions. A Guide for Professionals, Prepared by the Canadian Association for Community Living.

18. Legal capacity of persons with intellectual disabilities and persons with mental health problems. European Union Agency for Fundamental Rights, 2013.

19. Legal Capacity in Europe. A Call to Action to Governments and to the EU. MDAC, 2013.

20. "Models of implementation of Person of Trust Program in Primary Mental Health Care Centres, psychiatric hospitals and closed long-term residential institutions", Vilnius, 2010.

21. “Supported Decision-Making Agreements: could this help me?” Downloadable brochure http://www.hss.gov.yk.ca/downloads/supported_dm_booklet.pdf(last accessed 17 July 2011).

22. Key elements of a system for Supported Decision-making. Inclusion International Position paper, 2008.

23. Monitoring report „Human rights in mental health care in Baltic States“. Vilnius, 2006; Monitoring report from the pilot monitoring visit within 5 mental heath institutions within the European project "Institutional treatment, Human rights and Care assessment" (ITHACA), 2010.

24. Handbook for Parliamentarians on the Convention on the Rights of Persons with Disabilities, 2006. 
25. Committee on the rights of people with disabilities, Concluding observations for state parties: CRPD/C/TUN/CO/1; CRPD/C/ESP/CO/1; CRPD/C/PER/CO/1;CRPD/C/ARG/CO/1; $\mathrm{CRPD} / \mathrm{C} / \mathrm{CHN} / \mathrm{CO} / 1$; $\mathrm{CRPD} / \mathrm{C} / \mathrm{HUN} / \mathrm{CO} / 1$.

26. „6.5 thousand persons with established incapacity will not be able to participate in the elections", available at http://www.bernardinai.lt/index.php?url=articles/93636 (last accessed 04.02.2011).

\section{Pagalbos priimti sprendimus modelis kaip priemonè psichosocialinę negalią turinčių asmenų socializacijai: teisiniai ir švietimo iššūkiai Lietuvoje}

Dovilè Juodkaitè

Asociacija „Lietuvos neigaliųjų forumas“, Žemaitès g. 21, 03118 Vilnius, dovile.juodkaite@gmail.com

\section{Santrauka}

Asmenų, turinčių negalią, socialinei integracijai užtikrinti yra itin svarbi socializacija, kaip asmens socialinès patirties kaupimas, perèmimas ir atgaminimas aktyviai veikiant, priimant sprendimus, bendraujant ir susikuriant atitinkamą socialinị statusą. Straipsnio tikslas - supažindinti su nauja pagalbos priimti sprendimus koncepcija. Pagalbos priimti sprendimus modelis kaip priemonè yra numatyta naujame žmogaus teisių dokumente - JT Neigaliųjų teisių konvencijoje (Konvencija). Ši priemonè padeda asmenims, turintiems negalią, tinkamai igyvendinti visas savo teises. Nauja pagalbos priimti sprendimus koncepcija kelia daug iššūkių teisiniu, socialiniu, švietimo aspektais, kaip tinkamai ịdiegti ir igyvendinti ši modeli praktikoje, kad būtų apsaugotos teisès ir užtikrinta efektyvi socialinė integracija ir socializacija vienos iš labiausiai pažeidžiamų asmenų grupių - psichosocialinę negalia turinčių asmenų.

Atlikta teisinè studija siekẻ šių konkrečių uždavinių: apžvelgti naujus teisinius reikalavimus, kurie ịtvirtinti Konvencijos 12 str., numatančius lygybės prieš įstatymą nuostatas visiems asmenims, turintiems negalią; kritiškai išanalizuoti Lietuvos teisinę bazę bei jos nuostatas dèl teisinio neveiksnumo instituto, įvertinant jų atitikimą (neatitikimą) 
tarptautiniams reikalavimams; apžvelgti ir išanalizuoti pagalbos priimti sprendimus modelio pagrindinius kriterijus bei egzistuojančias kitų šalių praktikas; remiantis atlikta lyginamąja analize, pateikti išvadas ir rekomendacijas dèl Lietuvos teisinės bazės tobulinimo, reikalingų teisinių, socialinių paslaugų bei švietimo pagalbos priemonių, siekiant diegti bei igyvendinti pagalbos priimti sprendimus modelị Lietuvoje, užtikrinant visų psichosocialinės negalios asmenų, kaip teisès subjektų, veikimą ir teisių realizavimą bei pagarbą jų žmogiškajam orumui.

Esminiai žodžiai: asmenys, turintys negalia, socialine integracija, neigaliujų teisess, lygybe prieš įstatymą, teisinis veiksnumas, pagalba priimti sprendimus.

Itteikta / Received 2014-08-25

Priimta / Accepted 2014-12-12 